\title{
Hubungan antara Forgiveness dengan Resiliensi pada Penyintas Pasca Konflik di Aceh
}

\author{
Rifda Salsabila ${ }^{1}$, Diah Karmiyati ${ }^{2}$, Udi Rosida Hijrianti ${ }^{3}$ \\ Fakultas Psikologi, Universitas Muhammadiyah Malang \\ e-mail: ${ }^{1}$ ilasalsabila1701@gmail.com
}

\begin{abstract}
Conflicts of human rights violations have taken place between GAM (Gerakan Aceh Merdeka) and the Indonesian government in Aceh which have created feelings of heartache, trauma, fear and pressure, resulting in negative emotions that tend to stick to conflict survivors. To overcome the negative emotions and pressures, it is necessary to have forgiveness capabilities that can bring positive emotions as one of the submber resilience. The purpose of this study is to know the relationship between forgiveness and resilience of postconflict survivor in Aceh. The research design used quantitative nonexperimental study correlational with 2 variables. Cluster random sampling is used in term to determine the sampling method in Aceh Besar, Bireuen and Banda Aceh with participants is $(N=427)$. Nashori (2012) and Septia (2018) with CVR scale from Reivich and Shatte (2000) are used as instrument to determine the reseratch. The data is analysed by using Pearson product moment of utilizing the SPSS 21.0 program. The result showed that ( $r$ ) mark was 0.122 with $p$ was $0.012<0.05$ and the result research is there is a significant correlation between forgiveness and resilience. The contribution of forgiveness to resilience was $15 \%(r 2=0.015)$.
\end{abstract}

KEYWORDS forgiveness, resilience, postconflict survivor

CITATION Salsabila, R., Karmiyati, D., \& Hijrianti, U. (2019). Hubungan antara fogiveness dengan resiliensi pada penyintas pasca konflik di aceh. Cognicia, 7, (1), $62-76$.

Konflik merupakan suatu situasi atau kondisi yang menggambarkan pertikaian, perselisihan, maupun kesalahpahaman antara dua orang atau lebih dan antara dua golongan atau lebih, sebab terjadinya konflik karena dua belah pihak atau lebih percaya bahwa mereka memiliki ketidak selarasan tujuan atau suatu perjuangan untuk mendapatkan status, kekuasaan, dan sumber daya yang tujuannya adalah untuk meniadakan saingan. Salah satu konflik yang pernah terjadi di Indonesia terdapat di Nanggroe Aceh Darussalam. Konflik di daerah Aceh di latarbelakangi oleh lengsernya Bapak Ir.H. Soeharto dalam kerusuhan politik pada bulan Mei 1998. Konflik ini terjadi antara GAM (Gerakan Aceh Merdeka) dengan pemerintah RI (Republik Indonesia) dengan kasus pelanggaran hak asasi manusia. Pada peristiwa tersebut, warga sipil memegang peran yang besar dalam melakukan perubahan megenai paradigma kemerdekaan yang sudah diperjuangkan oleh GAM sebagai tuntutan sejarah daerah, karena Aceh merupakan bangsa yang berdaulat yang dituntut oleh kehidupan demokrasi. 
Konflik yang terjadi di Aceh mampu menghancurkan hampir semua sistem, baik dalam pemerintahan, tali persaudaran yang telah terjalin sejak dahulu, perekonomian, sosial dan budaya daerah Aceh. Akibat dari konflik pelanggaran hak asasi manusia tersebut, banyak peristiwa yang terjadi seperti penyekapan dan pembunuhan berencana atas orangorang yang diduga memiliki hubungan dengan pemerintah. Banyak pelanggaran tersebut yang merupakan kejahatan menurut hukum internasional, di samping terdapat indikasi kejahatan kemanusiaan dan kejahatan perang. Konflik yang dialami masyarakat Aceh menyebabkan beberapa individu mengalami gejala PTSD, gejala mental, keputusasaan, ketakutan dalam menjalani kembali kehidupan secara normal, adanya ketidakmampuan dalam mengatasi stress, beradaptasi kembali terhadap lingkungan yang baru, ketakutan akan bangkit serta bertahan untuk menjalani kehidupan yang baru dan menyesuaikan diri dengan kondisi yang baru setelah terjadinya konflik dan perang tersebut. Vijayakumar, Thara, John, dan Chellepa (2006) menjelaskan bahwa anakanak dan remaja lebih rentan kena dampak kejadian traumatis dibandingkan orang dewasa, karena mereka akan merasakan "helplessness and passivity, lack of usual responsiveness, generalized fear, heightened arousal and confusion".

Akibat peristiwa tersebut juga menyebabkan individu mengalami depresi, trauma, ketakutan, putus asa bahkan bunuh diri, mengindikasikan bahwa individu tersebut memiliki psikologis yang lemah, emosi yang belum cukup stabil apabila orang disekitar mengungkit kembali kejadian di masa lalu tersebut. Namun menurut Bilgin dan Taş (2018) beberapa individu mungkin dapat dengan cepat untuk pulih dan kembali ke kehidupan normal mereka bahkan beradaptasi dengan kehidupan baru setelah peristiwa traumatis, sementara beberapa orang lainnya mungkin mengalami masalah psikologis jangka panjang yang membutuhkan waktu bagi mereka untuk kembali ke kondisi normal dan beradaptasi dengan situasi baru. Kemampuan seseorang untuk bangkit dari kesulitan atau membangun kembali kehidupan yang baru memang memiliki cara ataupun tingkat yang berbedabeda. Akan tetapi, pada konflik yang telah dialami oleh masyarakat Aceh, menjadikan suatu penilaian untuk mengukur apakah penyintas konflik tersebut sudah dapat kembali pada kehidupan normalnya dan menjalankan aktivitas atau kegiatan sosial, mengontrol emosi, pikiran serta lisan saat bertemu pada pelaku yang telah menyakitinya. Atas kejadian konflik pelanggaran hak asasi manusia tersebut, salah satu kemampuan yang dapat ditumbuhkan pada penyintas konflik yaitu resiliensi. Resiliensi sebagai proses individu untuk memiliki ketahanan hidup dan bangkit dari kejadian yang menyakitkan. Padesky dan Mooney (2012) menjelaskan bahwa resiliensi sebagai suatu proses, bukan sifat, dan mendefinisikannya sebagai kemampuan untuk mengatasi dan beradaptasi dengan kondisi yang sulitbahkan dapat memulihkan fungsi kognitif kearah yang positif ketika stress ataupun mengalami trauma. Berdasarkan pendapat Padesky dan Mooney (2012), penyintas konflik yang memiliki resiliensi tinggi, ia dapat berasosiasi yang menunjukkan hasil positif dalam berbagai area seperti kesehatan fisik, perilaku yang sehat, performansi dalam edukasi, pekerjaan, penghasilan dan penurunan pada tindak kriminal.

Dari penelitian yang telah dilaksanakan oleh team peneliti dari Universitas Harvard dan International Organization for Migration pada awal tahun 2006, 
mendapatkan hasil bahwa terdapat beberapa daerah yang berkonflik tinggi seperti Bireuen, Pidie, dan Aceh Utara. Team menunjukkan hasil bahwa 65\% mengalami gejala depresi, dan 34\% lainnya mengalami Post Traumatic Stress Disorder (PTSD). Pada bulan Juli 2006, daerah Pesisir Timur seperti Aceh Timur dan Aceh Tamiang juga terkena dampak konflik intensif dengan jangka waktu yang panjang. Daerah tersebut menunjukkan hasil sebanyak 33\% mengalami gejala depresi dan 8\% mengalami PTSD. Terjadinya konflik tidak hanya memberikan dampak negatif bagi daerah setempat, namun terdapat dampak positif yaitu semakin baik tingkat keamanan dan rasa percaya terhadap proses perdamaian. Ratarata warga yang terkena dampak konflik yaitu menderita trauma atas peristiwa tersebut. Berdasarkan hasil survey didapatkan hasil bahwa dari 105 desa (74\%) melaporkan telah merasakan peperangan, 28\% mengalami penyiksaan, dan 38\% yang memiliki keluarga tersebunuh selama konflik terjadi. artinya, hampir setengah penduduk desa yang menjadi sampel penelitian (44\%) mengalami gejala tinggi pada depresi, 17\% PTSD, 48\% mengalami kecemasan yang berlebihan. (International Organiation for Migration dalam Batu dan Lumban, 2010).

Berdasarkan penelitian yang dilakukan oleh team Universitas Harvard dan International Organization of Migration, masalah yang dialami penyintas pasca konflik pelanggaran HAM yang telah terjadi di Aceh adalah munculnya gejala-gejala psikis yang dapat menimbulkan gangguan mental dalam jangka panjang. Dampak jangka panjang dari kejadian ini adalah timbulnya perasaan traumatic yang dapat menghambat perkembangan individu, menghambat proses adaptasi pada lingkungan yang baru dalam mengalami transformasi kehidupan apabila penyintas konflik pelanggaran hak asasi manusia di Aceh belum berproses dan menumbuhkan kemampuan resiliensi. Bluth, Mullarkey, dan Lathren (2018) menjelaskan bahwa proses resiliensi dapat digambarkan sebagai adaptasi positif terhadap pengalaman hidup yang buruk, dengan kata lain arahan/navigasi yang sukses ialah individu mampu membuktikan keberhasilan dalam melewati tantangan sesuai dengan tercapainya suatu tujuan hidup. Penyintas konflik dapat dikatakan mampu dan berhasil melewati pengalaman buruk tersebut ialah individu yang mampu menunjukkan kemajuan dan perkembangan dalam situasi yang kurang beruntung demi mendapatkan kesempatan hidup yang lebih baik di masa mendatang.

Duan, Guo, dan Gan (2015) berpendapat bahwa dalam pendekatan pertama, resiliensi diartikan sebagai pemulihan dari tingkat rendah setelah terjadinya peristiwa traumatis ke tingkat normal atau yang lebih tinggi sebelum terjadinya peristiwa traumatis. Oleh sebab itu, resiliensi merupakan proses bangkit dan berubahnya keadaan setelah penyintas konflik mengalami trauma. Konsep yang berbeda dari resiliensi psikologis yang diteliti dalam beberapa bidang seperti psikologi, psikiatri, sosiologi, neuroscience dapat didefinisikan sebagai kemampuan untuk mengatasi pengalaman negatif yang berhasil dan beradaptasi dengan kondisi kehidupan baru yang konsekuen. Konsep ini tidak mengacu pada perilaku atau sifat seorang individu dalam bidang tertentu tetapi karakteristik umumnya.

Yates, Tyrell, dan Masten (2015) menjelaskan resiliensi lebih tepat dikonseptualisasikan sebagai suatu proses perkembangan atau kapasitas dinamis individu, dari pada hanya sebagai hasil perubahan yang bersifat statis (tidak tetap). Masten (2014) mendefinisikan resiliensi sebagai kapasitas dari sistem dinamis pada 
individu untuk berhasil beradaptasi terhadap gangguan yang menganca, keberfungsian, kelangsungan hidup dan suatu pengembangan kehidupan. Seseorang dengan tingkat resiliensi yang tinggi, mampu mencerminkan bahwa dirinya siap untuk menghadapi dan menangani peristiwa dalam kehidupan yang dapat memunculkan gejala mental atau psikis. Individu atau penyintas yang mengalami kejadian tidak menguntungkan, lebih baik mengalami suatu proses resiliensi yang mengalami perkembangan, adanya perubahan disetiap waktu, dapat menunjukkan pemikiran dan perilaku yang positif, tidak hanya sebagai individu dengan hasil resiliensi yang bersifat sementara, tidak tetap bahkan menurun dalam mengalami transformasi akibat peristiwa buruk. Individu yang resiliensi mampu bertahan dalam menghadapi rintangan, bahkan bila perlu, mereka menerima sikap itu untuk tidak dapat diubah.

Reivich dan Shatte (2002) dalam bukunya "the resiliency factor" menjelaskan bahwa arti resiliensi itu adalah kemampuan untuk mengatasi dan beradaptasi bila terjadi sesuatu yang merugikan dalam hidupnya, bertahan dalam keadaan tertekan bahkan berhadapan dengan kesengsaraan (adversity) dialami sepanjang kehidupannya. Malkoç dan Yalçin (2015) menjelaskan bahwa individu yang resilien mampu mempertahankan kesehatan fisik dan psikologis milik individu tersebut serta memiliki kemampuan untuk pulih lebih cepat dari kejadian traumatis.

Penelitian yang dilakukan oleh Hitiyahubessy (2015) pada perempuan koban konflik Ambon sebagai sampel penelitian, yang secara nilai sosail dan budaya memiliki tingkat kebersamaan yang tinggi. Hasil menunjukkan bahwa subjek korban konflik Ambon memiliki kemampuan dalam beradaptasi dengan menumbuhkan kemampuan resiliensi untuk berhadapan dengan kehidupan setelah konflik. Dalam menunjukkan resiliensi sebagai proses, setiap individu mempunya kapasitas yang berbeda namun, mengalami nasib yang sama. Nilai sosial dan budaya yang dimaksud ialah pela gandong sebagai landasan dalam menjalankan membangun kembali kehidupan yang telah rusak. Karakteristik tersebut dapat meningkatkan kapasitas positif yan dijadikan sebagai fondasi untuk kembali bangkit dari keterpurukannya kondisi mereka, tidak mudah masuk dalam ketidakberdayaan dan mampu melihat peluang sebagai keberuntungan maupun manfaat dari kejadian traumatis.

La Fromboise, Hoyt, Oliver, dan Whitbeck (2006) menjelaskan bahwa resiliensi merupakan sebuah proses dan bukan atribut bawaan yang tetap. Resiliensi lebih akurat jika dilihat sebagai bagian dari perkembangan kesehatan mental yang dapat dipertinggi dalam siklus kehidupan seseorang. Proses resiliensi dapat dilatih dengan menanamkan pikiran positif pada individu. Selain itu, individu mampu beradaptasi dan mengembangkan kemampuan yang dimilikinya sebagai transformasi kehidupan. Individu dengan resiliensi yang rendah, tidak mampu dan ragu untuk merubah tujuan hidup, tidak berani untuk beradaptasi dengan lingkungan baru, dan takut atau terus menanamkan pikiran negatif. Vinayak dan Judge (2018) mendefinisikan resiliensi sebagai proses beradaptasi dengan lebih baik dalam menghadapi pengalaman buruk, trauma, tragedi, konflik, ancamanm atau stres yang bersumber dari dalam diri sendiri, keluarga, lingkungan sekitar, hubungan interpersonal, dan sebagainya. Resiliensi sebagai suatu kemampuan dalam mempersiapkan individu untuk melawan dan tetap waspada mengenai segala risiko yang terjadi akibat peristiwa traumatik. Artinya 
dalam meningkatkan proses dan kemampuan resiliensi dibutuhkan faktor yang dapat mendukung dan mempengaruhi resiliensi.

Salah satu faktor yang dapat mempengaruhi resiliensi yaitu berasal dari human strength (kekuatan individu) yang dimilikinya. Strenght of character human strength oleh Petterson \& Seligman (2004) diartikan sebagai karakter mencakup perbedaan individual yang bersifat stabil dan general, tetapi juga berubah. Strenght of character merupakan karakter baik untuk mengarahkan individu pada pencapaian kebajikan (virtue), atau trait positif yang direfleksikan dalam pikiran, perasaan maupun tingkah laku. Karakter yang baik adalah kualitas dari individu yang membuat individu dipandang baik secara moral. Dan salah satu human strength yang dijadikan variabel dalam penelitian ini adalah forgiveness (pemaafan/memaafkan).

Peterson \& Seligman (2004) mengatakan bahwa individu dengan strength of character ini mampu memaafkan orang yang telah melakukan kesalahan atau bersikap buruk padanya. Individu tersebut dapat melupakan pengalaman buruk di masa lalunya tanpa paksaan dari orang lain. Adanya upaya memberi kesempatan terhadap kesalahan yang dilakukan dan tidak berusaha untuk balas dendam atau ancaman (perintah penahanan) tapi dari kekuatan positif dari karakter pengampunan dan belas kasihan. Pemberian maaf menimbulkan sejumlah perubahan bermanfaat pada seseorang yang telah diganggu atau disakiti oleh orang lain. Ketika orang memaafkan, motivasi dasar atau tendensi tindakannya terhadap pelaku menjadi lebih positif (mulia, baik hati, atau murah hati) dan kurang negatif (menaruh dendam atau menghindar). Satu satunya kekuatan yang dapat menghentikan arus ingatan terhadap rasa sakit adalah memaafkan.

Penelitian yang telah dilakukan oleh Sari (2018) terhadap 50 subjek perempuan yang mengalami kekerasan dalam rumah tangga (KDRT). Berdasarkan hasil penelitian, ditemukan bahwa terdapat 27 subjek (54\%) perempuan mengalami KDRT dengan tingkat pemaafan yang tinggi, 13 subjek (26\%) perempuan mengalami KDRT dengan kategori sedang, 8 subjek (15\%) perempuan mengalami KDRT dengan kategori sangat tinggi dan 2 responden (4\%) perempuan mengalami KDRT dengan kategori rendah. Hasil penelitian tersebut menunjukkan bahwa sebagian besar perempuan yang mengalami KDRT mampu untuk memberikan maaf dengan baik. Selain itu, sebanyak 31 subjek (62\%) memiliki tingkat resiliensi yang sangat tinggi, 16 subjek (32\%) memiliki resiliensi yang tinggi, dan 3 subjek (6\%) dengan tingkat resiliensi sedang. Hasil ini menunjukkan bahwa perempuan yang mengalami KDRT memiliki tingkat resiliensi yang baik, dan semakin baik pula kemampuan perempuan KDRT dalam menjalin hubungan yang menguntungkan dengan orang lain, lingkungan, dan tidak mengandalkan bantuan individu disekitar serta memikirkan akan pentingnya sebuah perencanaan kehidupan di masa depan.

Forgiveness merupakan salah satu dari berbagai kajian dalam psikologi positif, yaitu pendekatan ilmiah dan terapan untuk mengungkap berbagai kekuatan seseorang dan mendorong fungsi positif pada diri mereka. Van Der Wal, Karremans, dan Cillesen (2016) mengatakan bahwa forgiveness adalah dapat dikaitkan dengan kesejahteraan psikologis justru karena forgiveness dapat membantu individu dalam mempertahankan, memulihkan hubungan yang stabil dan kedekatan yang positif sesama individu lainnya. 
Bell, Kamble dan Fincham (2018) berpendapat bahwa forgiveness telah dikonseptualisasikan sebagai suatu perubahan motivasi dimana keinginan untuk membalas dendam atau menghindari pelaku berkurang. Akan tetapi, hal yang mendasari timbulnya kemampuan individu untuk memaafkan, khususnya untuk melanjutkan suatu hubungan, merupakan respons yang baik atau positif, contohnya dengan memberikan belas kasih, afeksi, perilaku pendekatan kepada pelaku. Hal tersebut memberikan penilaian yang positif dan rasa aman terhadap orang lain maupun individu itu sendiri. Hubungan yang dijalankan dengan perasaan yang tulus dan menyingkirkan pemikiran negatif, menghasilkan kualitas hubungan yang lebih erat pula. Seseorang dengan nilai forgiveness rendah, dapat memiliki nilai yang kuat terhadap rendahnya rasa empati. Forgiveness dapat dikonseptualisasikan sebagai transformasi motivasi di mana keinginan untuk membalas dendam dan menghindari pelaku berkurang.

Akhtar, Dolan, dan Barlow (2017), dalam sejumlah penelitian eksperimental yang telah dilakukan untuk menilai apakah forgiveness dapat mengurangi masalah kesehatan mental yang umum dan dalam beberapa kasus? Dan apakah forgiveness dapat memberikan hasil pada kepuasan pernikahan, rasa syukur, pengaruh positif, harga diri, harapan dan kesehatan spiritual? Hasil analisa menunjukkan bahwa nilai dari memaafkan (forgiveness) ini telah menemukan mereka dapat mengurangi depresi, kecemasan dan stres, bahkan dapat meningkatkan kesejahteraan subjektif.

Dalam kasus konflik pelanggaran hak asasi manusia yang terjadi di Aceh, forgiveness dapat diartikan sebagai sikap seseorang yang telah disakiti untuk tidak melakukan perbuatan balas dendam terhadap orang yang menyakiti. Sebaliknya muncul keinginan untuk berdamai dan berbuat baik terhadap orang yang menyakiti. Forgiveness dapat didefinisikan sebagai proses mengatur emosi negatif, kognisi, dan perilaku yang disebabkan oleh perilaku orang lain yang menyakitkan ke dalam emosi yang lebih netral atau positif, kognisi, dan perilaku terhadap pelaku (Van der Wal, et al, 2016). Watson, Rapee dan Todorov (2017) menjelaskan bahwa forgiveness telah terbukti menjadi strategi yang bermanfaat bagi korban dalam berbagai bentuk seperti pelecehan maupun trauma. Meskipun tidak ada definisi yang seragam tentang forgiveness dalam literatur, hal tersebut telah dikonseptualisasikan sebagai proses mengatasi, dimana stressor yang dihasilkan dari pandangan negatif seseorang dan dinetralkan melalui keputusan yang disengaja untuk tidak memendam perasaan kebencian maupun dendam, terhadap seseorang yang telah menyebabkan kerusakan, luka, ketidakadilan, dan sebagainya.

Dalam studi Kuzubova (2015) yang berfokus pada tiga dimensi forgiveness, yaitu intrapersonal (memaafkan diri sendiri), interpersonal (memaafkan orang lain, dan ilahi (mengetahui bahwa Tuhan Maha mengampuni). Selain itu, forgiveness merupakan pilihan sukarela yang digunakan oleh orang yang mengalami penderitaan luka secara tidak adil, dan untuk melepaskan hak atas kebencian dan pembalasan dendam dengan tidak mengungkapkan kejadian tersebut kepada pelaku (misalnya, meremehkan pelaku), kepada orang lain atau kepada diri sendiri, atau kepada lingkungan. Forgiveness merupakan suatu proses interpersonal yang dipilih untuk kepentingan membebaskan diri dari kemarahan. 
Pada penelitian yang dilakukan oleh Adawiyah (2018) terhadap 114 subjek, dengan remaja yang berusia 11 - 20 tahun yang bertempat tinggal di panti asuhan. Hasil penelitian menunjukkan bahwa terdapat hubungan yang signifikan antara memaafkan dan kesejahteraan psikologis remaja panti asuhan. Memaafkan perbuatan seseorang yang berakibat konflik, dapat memperbaiki suatu hubungan yang buruk menghasilkan hubungan yang baik, atau dengan kata lain terjalin kembali hubungan yang lama dengan kondisi atau pengalaman baru. Ketika individu mempunyai suatu masalah dengan individu atau kejadian lainnya, maka sikap memaafkan dapat berperan dalam situasi negatif menjadi suatu respon positif (Flanagan, Hoek, Ranter \& Reich, 2012).

Berdasarkan uraian diatas, rumusan masalah terkait penelitian ini ialah apakah terdapat hubungan antara forgiveness dengan resiliensi pada penyintas pasca konflik di Aceh? Rumusan masalah tersebut berdasarkan atas ketertarikan yang dikarenakan belum terdapat penelitian yang menghubungkan forgiveness dan resiliensi pada penyintas pasca konflik pelanggaran hak asasi manusia di Aceh. Perbedaan penelitian adalah penelitian ini dilakukan di Nanggroe Aceh Darussalam, tepatnya di daerah Janthoe, Blang Bintang Aceh Besar, Jenib, Matang, dan Peusangan Kabupaten Bireuen, dan Banda Aceh (Lambaro Skep), yang dilihat dari tingkat keparahan konflik pada setiap daerah penelitian.

Diharapkan penelitian ini dapat bermanfaat dan tambahan bagi pengembangan ilmu psikologi, khususnya pada psikologi klinis, psikologi positif, dan psikologi sosial dengan mempelajari kondisi maupun pengalaman traumatik yang dialami penyintas pasca konflik sebagai penyintas yang memiliki karakter untuk menjadikan mereka sebagai individu yang kuat. Kemudian untuk pihak yang libat, diharap penelitian ini dapat membantu untuk memberi informasi terhadapnya pentingnya menumbuhkan kemampuan forgiveness demi menghindari terjadinya tingkah laku yang tidak resilient untuk kehidupannya di masa mendatang.

\section{METODE}

Penelitian ini menggunakan metode kuantitatif noneksperimen yang merupakan suatu pendekatan dengan mengumpulkan data penelitian berupa data kuantitatif dan diolah menggunakan teknik statistik. Desain penelitian yang digunakan dalam penelitian ini adalah korelasional dengan teknik analisis korelasi Pearson product moment. Azwar (2010) menjelaskan bahwa penelitian kuantitatif korelasional bertujuan untuk menyelidiki sejauh mana variasi pada suatu variabel yang berkaitan dengan variasi pada satu atau lebih variabel lain, berdasarkan koefisien korelasi. Selain bertujuan untuk mengetahui ada atau tidaknya hubungan antar kedua variabel, namun juga untuk menjelaskan dan memprediksi suatu kejadian yang berhubungan dengan variabel penelitian.

Subjek pada penelitian ini berjumlah 427 subjek yang merupakan penyintas dari terjadinya konflik pelanggaran hak asasi manusia di Aceh. Populasi dan sampel penelitian dipilih berdasarkan pada daerah dengan tingkat keparahan tinggi, sedang dan aman saat terjadinya konflik. Daerah yang dipilih untuk pengambilan data penelitian yaitu Aceh Besar: Blang Bintang dan Jantho, Bireuen: Peusangan, Pante Gajah dan Matang/Jinieb, dan Banda Aceh. Pengambilan sampel menggunakan teknik 
probability sampling, dimana semua individu memiliki kesempatan yang sama untuk dipilih menjadi partisipan penelitian. Teknik yang digunakan adalah cluster random sampling, yang mana populasi tidak terdiri dari individuindividu, melainkan terdiri dari kelompokkelompok individu atau cluster. Teknik sampling daerah digunakan untuk menentukan sampel bila objek yang diteliti atau sumber data sangat luas. Pemilihan teknik tersebut karena peneliti tidak mengetahui secara pasti jumlah dari korban konflik yang terdapat di Aceh, sehingga peneliti menetapkan ciri-ciri subjek penelitian.

Adapun kriteria subjek diantaranya adalah sebagai berikut, (1) merupakan penyintas dari pasca konflik GAMRI sejak DOM (Daerah Operasional Militer) pada tahun 1989 hingga 2005; (2) subjek dengan berusia 29 - 90 tahun; (3) individu berada dan langsung mengalami secara nyata pada kejadian konflik pelanggaran hak asasi manusia; (4) subjek berada pada daerah dengan tingkat keparahan konflik tinggi, sedang dan daerah yang aman dari konflik.

Penelitian ini terdapat dua variabel yaitu variabel bebas $(X)$ dan variabel terikat (Y). Adapun yang menjadi variabel bebas (X) (independent variable) ialah forgiveness, sedangkan variabel terikat $(\mathrm{Y})$ (dependent variable) ialah resiliensi.

Resiliensi adalah kemampuan seseorang untuk bangkit dan bertahan dari masa sulit serta dapat mengatasi atau beradaptasi terhadap stres yang ekstrim akibat kejadian di masa lalu dan kesengsaraan dalam kehidupan yang dialaminya. Individu yang resilient dianggap memiliki resiliensi yang baik apabila mereka mampu untuk secara cepat kembali kepada kondisi sebelum trauma dan terlihat kebal dari berbagai peristiwaperistiwa kehidupan yang negatif. Resiliensi psikologi dapat diartikan suatu proses transformasi kehidupan berdasarkan pengalaman menyakitkan yang dialami, terdapat emosi positif, dan meninggalkan perasaan serta pikiran pada ketakutan untuk beradaptasi pada lingkungan baru.

Pada variabel resiliensi, menggunakan skala berdasarkan penelitian Septia (2018) yang disusun dengan mengacu pada aspek resiliensi pada skala CVR (Reivich dan Shatte) yaitu emotion regulation, impulse control, causal analysis, self efficacy, optimism, empathy dan reaching out. Skala ini berjumlah 44 item sebelum uji coba dan menjadi 40 aitem setelah melalui uji coba. Pernyataan dari skala tersebut dimodifikasi sesuai kebutuhan penelliti pada subjek tertentu. Skala penelitian ini berjenis skala likert. Sugiyono (2013) menjelaskan bahwa skala likert dapat mempunyai gradasi sangat positif hingga sangat negatif, sedangkan respon jawaban yang dibarikan pada subjek adalah berupa kata-kata 'sangat sering" (SS), "sering" (S), "tidak sering" (TS), "sangat tidak sering" (STS) karena aitem pernyataan yang diukur adalah perilaku. Skala dalam penelitian ini memiliki empat pilihan jawaban pernyataan yaitu SS (sangat setuju), S (setuju), TS (tidak setuju) dan STS (sangat tidak setuju).

Forgiveness merupakan perilaku memaafkan yang terdapat pada individu untuk meredakan kebencian terhadap pihak yang menyakiti, mengubah individu untuk tidak membalas dendam serta meningkatkan dorongan untuk memperbaiki hubungan dengan pihak yang menyakiti. Forgiveness yang dimaksudkan dalam penelitian ini adalah bentuk penilaian pemaafan penyintaspasca konflik hak asasi manusia yang terjadi di Aceh, terhadap individu/kelompokkelompok yang menyakiti perasaan, keluarga dan membuat pengalaman yang mengerikan pada masa tersebut. 
Pada variabel forgiveness, peneliti menggunakan skala penelitian dari Nashori (2012) yang tersusun berdasarkan tiga dimensi forgiveness yaitu dimensi emosi, dimensi kognitif dan dimensi interpersonal. Skala ini digunakan untuk mengukur tingkat forgiveness yang terdapat pada penyintas konflik berdasarkan aspek fogiveness yang telah dijelaskan oleh Nashori (2012). Hasil analisis menunjukkan bahwa skala forgiveness yang telah diuji coba, terdapat 15 aitem yang tidak valid dari total 42 aitem pernyataan. Sehingga aitem yang valid berjumlah 27 aitem pernyataan. Skala dalam penelitian ini menggunakan skala likert, dengan 27 pernyataan yang dimodifikasi sesuai kebutuhan peneliti saat ini. Dalam skala penelitian tersebut terdapat lima pilihan jawaban, yaitu "sangat jarang terjadi", "jarang terjadi", "kadang-kadang terjadi", "sering terjadi", dan "sangat sering terjadi".

Berdasarkan uji reliabilitas pada skala forgiveness dan resiliensi, didapatkan hasil bahwa skala forgiveness terdapat 11 aitem yang dinyatakan valid dari 27 aitem pernyataan setelah dilakukannya uji coba, sehingga terdapat 16 aitem yang gugur berdasarkan skala penelitian Nashori (2012), dengan indeks reliabilitas sebesar $=0.913$. Sedangkan pada skala resiliensi terdapat $44 \alpha$ aitem yang diadaptasi dari skala Septia (2018), sehingga menjadi 41 aitem pernyataan yang diadaptasi sesuai dengan kebutuhan peneliti. Setelah dilakukan uji coba, diperoleh 22 aitem valid dari 41aitem, sehingga terdapat 18 aitem yang gugur pada proses uji coba dengan indeks reliabilitas $=0.900 . \alpha$

\section{HASIL}

Subjek yang berpartisipasi dalam penelitian ini dan sesuai dengan kriteria yang telah peneliti tetapkan untuk kebutuhan penelitian berjumlah 427 subjek. Berikut deskripsi subjek penelitian:

Tabel 1. Deskripsi Subjek Penelitian

\begin{tabular}{lcc}
\hline \multicolumn{1}{c}{ Karakteristik } & Frekuensi & Persentase \\
\hline Jenis Kelamin & & \\
$\quad$ Laki-laki & 188 & $44 \%$ \\
$\quad$ Perempuan & 239 & $56 \%$ \\
\hline Usia & & \\
29 Tahun & 1 & $0.2 \%$ \\
30 - 39 Tahun & 140 & $32.8 \%$ \\
$40-49$ Tahun & 129 & $30.8 \%$ \\
$50-59$ Tahun & 120 & $28 \%$ \\
$60-69$ Tahun & 25 & $2.7 \%$ \\
\hline
\end{tabular}

Berdasarkan pada tabel 1 mengenai deskripsi subjek penelitian didapatkan hasil bahwa, pada usia 30 - 39 tahun terdapat 140 subjek (32.8\%) merupakan penyintas pasca konflik di Aceh dan termasuk usia yang lebih banyak menjadi penyintas korban konflik dan yang mengalami kejadian bahkan merasakan dampak dari peristiwa konflik.

Tabel 2. Kategorisasi Forgiveness Berdasarkan Lokasi/Daerah Penelitian 


\begin{tabular}{lcc}
\hline \multirow{2}{*}{ Kategori } & \multicolumn{2}{c}{ Forgiveness } \\
\cline { 2 - 3 } & Tinggi & Rendah \\
\hline Aceh Besar & $156(36.5 \%)$ & $44(10.3 \%)$ \\
Pante Gajah & $36(8.4 \%)$ & $63(14.8 \%)$ \\
Peusangan & $30(7 \%)$ & $18(4.2 \%)$ \\
Matang & $4(0.9 \%)$ & $48(11.2 \%)$ \\
Banda Aceh & $8(1.9 \%)$ & $20(4.7 \%)$ \\
\hline \multicolumn{1}{c}{ Total } & $\mathbf{2 3 4} \mathbf{( 5 4 . 8 \% )}$ & $\mathbf{1 9 3} \mathbf{( 4 5 . 2 \% )}$ \\
\hline
\end{tabular}

Pada tabel 2 yaitu variabel forgiveness yang diukur berdasarkan daerah penelitian, didapatkan hasil bahwa pada daerah Aceh Besar termasuk daerah dengan tingkat forgiveness yang tinggi dengan persentase yaitu 36.5\% dan daerah Banda Aceh merupakan daerah dengan tingkat forgiveness yang rendah yaitu 1.9\%. Hasil tersebut diukur berdasarkan pada tingkat keparahan terjadinya konflik.

Tabel 3. Kategorisasi Resiliensi Berdasarkan Lokasi/Daerah Penelitian

\begin{tabular}{lcc}
\hline \multirow{2}{*}{ Kategori } & \multicolumn{2}{c}{ Resiliensi } \\
\cline { 2 - 3 } & Tinggi & Rendah \\
\hline Aceh Besar & $82(19.2 \%)$ & $118(27.6 \%)$ \\
Pante Gajah & $42(9.8 \%)$ & $57(13.3 \%)$ \\
Peusangan & $30(7 \%)$ & $18(4.2 \%)$ \\
Matang & $43(10.1 \%)$ & $9(2.1 \%)$ \\
Banda Aceh & $7(1.6 \%)$ & $21(4.9 \%)$ \\
\hline \multicolumn{1}{c}{ Total } & $\mathbf{2 0 4 ( 4 7 . 8 \% )}$ & $\mathbf{2 2 3 ( 5 2 . 2 \% )}$ \\
\hline
\end{tabular}

Pada tabel 3 dengan variabel resiliensi yang diukur berdasarkan daerah penelitian, didapatkan hasil bahwa pada daerah Aceh Besar memiliki tingkat resiliensi rendah dengan persentase yaitu $27.6 \%$ yang dapat dilihat dari banyaknya subjek penelitian yaitu 118 subjek penelitian.

Tabel 4. Kategorisasi Forgiveness dan Resiliensi Berdasarkan Jenis Kelamin

\begin{tabular}{lcccc}
\hline \multirow{2}{*}{ Kategori } & \multicolumn{2}{c}{ Forgiveness } & \multicolumn{2}{c}{ Resiliensi } \\
\cline { 2 - 5 } & Tinggi & Rendah & Tinggi & Rendah \\
\hline Laki-laki & $99(23.2 \%)$ & $89(30.8 \%)$ & $75(17.6 \%)$ & $113(26.5 \%)$ \\
Perempuan & $135(36.6 \%)$ & $104(24.4 \%)$ & $129(30.2 \%)$ & $110(25.8 \%)$ \\
\hline
\end{tabular}

Pada tabel 4 dengan pengukuran forgiveness dan resiliensi yang dilihat secara gender. Didapatkan hasil bahwa pada perempuan memiliki skor yang tinggi yaitu $36.3 \%$ dari pada subjek laki-laki dengan jumlah $23.2 \%$ pada variabel forgiveness. Dan pada variabel resiliensi, subjek juga memiliki skor yang tinggi yaitu $30.2 \%$ dibandingkan subjek lakilaki yaitu $26.5 \%$. Hasil ini menunjukkan bahwa perempuan memiliki tingkat forgiveness dan resiliensi yang tinggi dibandingkan laki-laki.

\section{DISKUSI}


Berdasarkan penelitian yang telah dilakukan, hasil menunjukkan terdapat hubungan positif yang signifikan antara forgiveness dan resiliensi pada penyintas pasca konflik pelanggaran hak asasi manusia di Aceh ( $\mathrm{r}=0.122 ; \mathrm{p}=0.012<0.05)$. Hasil penelitian ini menunjukkan bahwa semakin tinggi tingkat forgiveness maka semain tinggi resiliensi penyintas konflik pelanggaran hak asasi manusia di Aceh. Sebaliknya semakin rendah tingkat forgiveness maka semakin rendah tingkat resiliensi penyintas konflik pelanggaran hak asasi manusia di Aceh. Hal ini didukung oleh penelitian dari Worthington dan Scherer (2004) menyatakan bahwa pemaafan (forgiveness) dapat mempengaruhi resiliensi dengan kondisi kesehatan individu melalui baiknya dukungan sosial dan kualitas hubungan interpersonal yang dimiliki.

Afshinmer, Weisi, Mortazavi, ZinatMotlagh, dan Mahboubi (2014) mengemukakan apabila semakin tinggi forgiveness individu dapat berproses untuk menghilangkan halhal negatif yang dirasakan dan mengembangkan hal-hal positif dalam diri, hal ini menuntut individu untuk dapat melakukan regulasi emosi yang baik selama proses memaafkan. Namun, dari hasil penelitian yang diperoleh, terdapat hasil yang berketidaksinambungan antara forgiveness dengan resiliensi. Hal ini didukung oleh 2 (dua) daerah dari 5 (lima) daerah penelitian yang memiliki hasil berbeda, yaitu pada daerah Aceh Besar memiliki skor yang lebih tinggi pada forgiveness yaitu $36.5 \%$, sedangkan skor yang lebih rendah pada resiliensi, yaitu $27.6 \%$, pada daerah Matang dengan skor forgiveness yang lebih rendah yaitu $11.2 \%$, sedangkan pada resiliensi yang memiliki skor lebih tinggi yaitu $10.1 \%$, dan terdapat satu daerah yang memiliki skor seimbang, yaitu terdapat pada daerah Peusangan dengan skor forgiveness yaitu $7 \%$ dan pada skor resiliensi yaitu 7\%. Hasil tersebut menyatakan bahwa forgiveness tidak menjadi faktor yang memiliki dukungan lebih pada resiliensi.

Hasil penelitian menunjukkan bahwa, resiliensi tidak menjadi salah satu faktor yang mendukung forgiveness. Hal tersebut dikarenakan resiliensi bukan lagi faktor yang menjadi tolak ukur setelah terjadinya konflik yang telah berlangsung selama \pm 30 tahun lalu. Dari hasil penelitian ini, kontribusi forgiveness yang dimiliki sebesar 15\%, menunjukkan bahwa forgiveness yang ditunjukkan bisa terjadi sebatas memaafkan secara fisik, namun tidak secara kognitif dan afeksi penyintas konflik. Dengan hasil tersebut, terjadi kemunculan dan tersimpannya perasaan dendam dan amarah yang masih dipendam oleh penyintas konflik. Dengan kontribusi forgiveness terhadap resiliensi hanya 15\%, mengartikan resiliensi sebagai ialah suatu proses dan pekembangan adaptasi positif terhadap pengalaman buruk dengan mengarahkan dan mampu membuktikan keberhasilan dalam melewati tantangan serta tekanan yang dialami (Bluth, Mullarkey, \& Lathren 2018). Dalam hal ini, penyintas konflik tidak lagi menunjukkan sikap ataupun kemampuan resiliensi, namun pembuktian proses perkembangan kehidupan yang mulai meningkat, tidak lagi mengingat peristiwa di masa lalu karena mengalami suatu perubahan pola kehidupan, melewati tekanan dari peristiwa traumatis tersebut.

Forgiveness juga bukanlah satusatunya variabel yang dapat mempengaruhi resiliensi pada penyintas pasca konflik pelanggaran hak asasi manusia di Aceh. Namun juga ditemukan bahwa terdapat faktor lainnya yang dapat mempengaruhi resiliensi. Herrman, Stewart, Diaz, Berger, Jakcson, dan, Yuen (2011) menjelaskan bahwa faktorfaktor yang dapat mempengaruhi resiliensi meliputi dalam beberapa hal, 
pertama faktor biologis dan kedua faktor kepribadian, yang meliputi karakteristik kepribadian, selfefficacy, selfesteem, internal locus of control, optimisme, intelektual, pengonsepan diri yang positif, ketahanan, regulasi emosi dan sebagainya. Reivich dan Shatte (2002) juga menjelaskan bahwa terdapat faktor yang dapat mempengaruhi tingginya tingkat kemampuan resiliensi yaitu faktor protektif. Faktor ini mengarahkan pada perbaikan atau perlindungan individu dari risiko saat menghadapi kondisi yang malang. Faktor protektif memiliki peran penting dalam mengubah emosi negatif dari lingkungan yang merugikan serta dapat menguatkan resiliensi seseorang. Faktor protektif berasal dari karakteristik individu. Salah satu karakteristik individu tersebut yaitu forgiveness. Karena dengan memaafkan dapat muncul dari diri inidvidu tersebut, sehingga dengan memaafkan perbuatan atau kesalahan pelaku, individu mampu menjadi seseorang dengan resilien yang tinggi.

Karakteristik pada penyintas pasca konflik di Aceh yang dapat mencerminkan memiliki kemampuan resiliensi yang tinggi adalah individu tersebut mampu berproses dengan baik dan cepat dalam memulihkan kondisi, mudah bersosialisasi, memiliki kemampuan untuk membangun lingkungan yang baru, mampu melawan pada keadaan yang membuat ia tertekan, stres bahkan trauma psikis yang dialami. Namun, berdasarkan hasil penelitian yang berada pada kategori daerah penelitian, tingkat resiliensi di daerah Aceh Besar, Pante Gajah dan Banda Aceh pada skor yang rendah. Meichenbaum (2007) juga telah menjelaskan bahwa kemampuan resiliensi yang tingi adalah dapat mencerminkan kemampuan individu untuk mempertahankan keseimbangan kondisi yang stabil dan kesehatan mental yang relatif stabil pada tingkat fungsi psikologis dan fisik. Namun, pada hasil penelitian ini keterkaitan antara forgiveness dengan resiliensi tidak seimbang. Terdapat daerah dengan forgiveness yang tingga dengan resiliensi yang rendah, dan terdapat pula forgiveness yang rendah namun resiliensi yang tinggi. Penyintas pacsa konflik Aceh apabila dilihat secara daerah yang terkena dampak konflik tinggi dan sedang, belum mampu mengalami pemulihan secara psikis terhadap trauma dan tekanan yang dialami dan belum mampu untuk menerima suatu perubahan positif berdasarkan pengalaman buruk yang terjadi terhadap ketahanan diri dan lingkungan yang baru.

Hasil penelitian terkait forgiveness dengan resiliensi tidak hanya diukur berdasarkan daerah penelitian, keterkaitan antara kedua variabel tersebut juga diukur secara gender. Berdasarkan hasil penelitian ini, didapatkan bahwa pada variabel forgiveness 135 subjek penelitian perempuan (24.4\%) lebih banyak dibandingkan subjek laki-laki yaitu 99 subjek penelitian (23.3\%), dari total keseluruhan subjek perempuan berjumlah 239 subjek dan 135 subjek laki-laki. Hal ini menjelaskan bahwa perempuan lebih mudah mengalami forgiveness dibandingkan lakilaki. Hasil pada penelitian ini didukung oleh penelitian yang dilakukan oleh Toussaint dan Webb (2005) menjelaskan bahwa perempuan lebih mudah memberikan forgiveness (memaafkan) Adibandingkan laki-laki, dengan alasan bahwa perempuan memiliki rasa empati dan memaafkan yang tinggi, perempuan juga lebih mudah terbawa perasaan terhadap dirinya sendiri, orang lain, dan lingkungan sekitarnya.

Kemudian pada penelitian yang diukur dengan variabel resiliensi, hasil penelitian menunjukkan bahwa 129 subjek perempuan (30.2\%) lebih mudah mengalami suatu perkembangan kehidupan dibandingkan lakilaki hanya 75 subjek 
penelitian (17.6\%) yang mengalami resiliensi. Hal ini sejalan dengan penelitian Sihite dan Saleeman (2014) yang menunjukkan hasil bahwa perempuan memiliki tingkat resiliensi yang tinggi dari pada laki-laki dengan adanya nilai resiliensi seperti security, conformity dan tradition. Hal tersebut dikarenakan perempuan mudah mencari dukungan sosial dengan menjalin hubungan untuk mendapat dukungan sosial pada orang lain sebagai salah satu faktor protektif dalam meningkatkan resiliensi (Herrman, dkk, 2011).

Berdasarkan hasil penelitian yang telah dijelaskan, sumbangan variabel forgiveness terhadap variabel resiliensi dapat diketahui dari koefisien determinasi $(\mathrm{R} 2=$ $R$ Squared) yakni sebesar 0.015. Hasil penelitian tersebut menjelaskan bahwa forgiveness memiliki sumbangan efektif sebesar $15 \%$ pada variabel resiliensi, sedangkan $85 \%$ lainnya merupakan beberapa faktor lain yang ditemukan saat pelaksanaan penelitian yang dapat mempengaruhi resiliensi. Dan juga terdapat beberapa keterbatasan dalam penelitian ini yaitu tidak teridentifikasinya penyebab variabel forgiveness hanya memiliki kontribusi yang mempengaruhi variabel resiliensi sebesar 15\%. Kemudian terdapat hubungan yang lemah antara forgiveness dengan resiliensi pada penyintas pasca konflik pelanggaran hak asasi manusia di Aceh. Selain itu, pernyataan pada skala forgiveness dan skala resiliensi tidak menggunakan bahasa yang mudah dipahami subjek, tidak dengan penggunaan bahasa daerah yang mayoritas subjek bertempat tinggal di perkempungan dan memiliki kekurangan dalam pemahaman bahasa Indonesia. Kemudian tidak semua subjek bersedia untuk mengisi kuesioner yang diberi oleh peneliti. Selanjutnya, terdapat pada keterbatasan usia pada subjek penelitian, dengan mempertimbangkan kembali penentuan dan batas usia yang digunakan dan perhitungan yang tepat dalam penentuan usia subjek penelitian. Untuk mengatasi permasalahan pada pengisian kuesioner, peneliti dapat menggunakan dan mempersiapkan metode yang berbeda dengan menggunakan teknik wawancara atau dengan mengambil pernyataan berdasarkan cerita yang diungkapkan oleh subjek penelitian.

\section{SIMPULAN DAN IMPLIKASI}

Berdasarkan penelitian yang telah dilakukan maka ditemukan bahwa terdapat hubungan positif yang signifikan antara forgiveness dengan resiliensi pada penyintas konflik pelanggaran hak asasi manusia di Aceh.

Implikasi dari penelitian mengenai forgiveness dengan resiliensi bagi beberapa lingkup, pertama bagi penyintas konflik pelanggaran hak asasi manusia di Aceh, diharapkan mampu memaafkan kesalahan, perbuatan menyakitkan yang dilakukan secara fisik maupun psikis dan tidak memiliki motivasi untuk balas dendam. Selain berkeinginan untuk melakukan perdamaian antar kelompok maupun individu untuk mendapatkan kualitas kehidupan yang lebih baik.

Kedua, bagi peneliti selanjutnya perlu diadakannya penelitian lanjutan untuk mengukur variabel resiliensi penyintas konflik yang tidak hanya ditinjau dari gender namun dengan faktor lain seperti selfefficacy, optimisme, pengonsepan diri dan sebagainya. Kemudian untuk penelitian selanjutnya mengenai forgiveness dengan resiliensi sebaiknya menjadi penelitian jangka panjang (longitudinal research) 
dikarenakan forgiveness dengan resiliensi merupakan suatu proses transformasi perilaku, pikiran, hubungan interpersonal, dan lingkungan sosial yang berkaitan dengan perasaan dan waku. Kemudian, implikasi pada peneliti selanjutnya untuk menyesuaikan kalimat atau bahasa dari pernyataan (aitem) skala penelitian dengan menggunakan bahasa daerah sesuai lokasi penelitian yang dituju. Dengan tujuan untuk lebih mempermudah subjek penelitian dalam memahami dan mengisi kuesioner/skala penelitian.

Ketiga bagi dinas sosial, lembaga kemasyarakatan dan lembaga layanan psikologi khususnya pada daerah yang terkena dampak konflik parah hingga sedang, agar diberikan bentuk pelatihan mengenai pentingnya dalam membangun kemampuan resiliensi dan karakter individu agar dapat memiliki ketahanan dan ketangguhan diri, mengingat resiliensi merupakan suatu kemampuan yang penting dalam merekonsiliasi kehidupan dan lingkungan sosial pasca terjadinya konflik di suatu daerah.

\section{REFERENSI}

Adawiyah, K. (2018). Korelasi forgiveness dengan psychological wellbeing pada remajapanti asuhan. Skripsi, Fakultas Psikologi Universitas Muhammadiyah Malang.

Afshinmer, H., Weisi, F., Mortazavi, S. S., ZinatMotlagh, F. \& Mahboubi, M. (2014). Relationship between Islamic coping styles and happines state in parents of exceptional children. Journal of Science and Today's World. 3(12), 567570.

Akhtar, S., Dolan, A., \& Barlow, J. (2017). Understanding the relationship between state forgiveness and psychological wellbeing: A qualitative study.Journal of religion and health, 56(2), 450463.

Akhtar, S., \& Barlow, J. (2018). Forgiveness therapy for the promotion of mental wellbeing: a systematic review and metaanalysis. Trauma, Violence, $\mathcal{E}$ Abuse, 19(1), 107122.

Batu, P., \& Lumban, M. (2010). Dinamika trauma psikologis pada dewasa awal paska konflik GAMRI di Aceh. Doctoral dissertation, Prodi Psikologi Univeristas Katolik Soegijapranata Semarang.

Bell, C. A., Kamble, S. V., \& Fincham, F. D. (2018). Forgiveness, attributions, and marital quality in US and Indian marriages. Journal of couple \& relationship therapy, 118

Bilgin, O., \& Taş, I. (2018). Effects of perceived social support and psychological resilience on social media addiction among university students. Universal Journal of Educational Research 6(4): 751758.

Bluth, K., Mullarkey, M., \& Lathren, C. (2018). SelfCompassion: A potential path to adolescent resilience and positive exploration. Journal of Child and Family Studies, 27(9), 30373047.

Duan, W., Guo, P., \& Gan, P. (2015). Relationships among trait resilience, virtues, posttraumatic stress disorder, and posttraumatic growth. PLoS One, 10(5).

Flanagan, K. S., Hoek, K. K. V., Ranter, J. M., \& Reich, H. A. (2012). The potential of forgiveness as a response for coping with negative peer experiences. Journal of Adolescence, 35(5), 12151223.

Herrman, H., Stewart, D. E., DiazGranados, N., Berger, E. L., Jackson, B., \& Yuen, T. (2011). What is resilience? The Canadian Journal of Psychiatry, 56(5), 258265.

Kuzubova, K. (2015). Forgiveness and depression among adolescents. Disertation Doctor of philosophy degree in counselor education and supervision, The Unisersity of Toledo.

LaFromboise, T. D., Hoyt, D. R., Oliver, L., \& Whitbeck, L. B. (2006). Family, community, and school influences on resilience among American Indian adolescents in the upper Midwest. Journal of community psychology, 34(2), 193-209. 
Malkoç, A., \& Yalçin, İ. (2015). Relationships among resilience, social support, coping, and psychological wellbeing among university students. Turkish Psychological Counseling and Guidance Journal, 5(43), 35-43.

Masten, A. S. (2014). Ordinary magic: Resilience in development. New York, NY: Guilford.

Meichenbaum, D. (2007). Important facts about resilience: A consideration of research findings about resilience and implications for assessment and treatment. Melissa Institute: Miami, FL, USA.

Nashori, F. (2012). Pemaafan pada etnis Jawa: Pengaruh religiositas dan keterikatan interpersonal terhadap pemaafan melalui perantara sifat kebersetujuan dan neurotisme (studi pada warga Yogyakarta). Disertasi, Program Pasca Sarjana Universitas Padjadjaran.

Padesky, C. A., \& Mooney, K. A. (2012). Strengths based cognitive-behavioural - therapy: A four step model to build resilience. - Clinical Psychology \& Psychotherapy, 19(4), 283290.

Peterson, C.,\& Seligman, M.E.P. (2004). Character strength and virtues: A handbook and classification. New York: Oxford University Press.

Reivich, K., \& Shatte, A. (2002). The resilience factor: 7 essential skills for overcoming life's invetible obstacles. Newyork: Broadway Book.

Sari, J. S. (2018). Hubungan antara pemafaan dan resiliensi pada perempuan yang mengalami kekerasan dalam rumah tangga. Skripsi, Fakultas Psikologi dan Ilmu Sosial Budaya Universitas Islam Indonesia Yoyakarta.

Septia, H. (2018). Hubungan dukungan sosial teman sebaya dan resiliensi remaja korban bencana di Pacitan. Skripsi, Fakultas Psikologi Universitas Muhammadiyah Malang.

Sihite, M. L., \& Saleeman, J. (2014). Hubungan antara resiliensi dan nilai pada pengungsi Halmahera di Bitung. Skripsi, Fakultas Psikologi Universitas Indonesia.

Sugiyono. (2013). Metode penelitian pendidikan pendekatan kuantitatif, kualitatif, dan rEd. Bandung: Alfabeta.

Toussaint, L., \& Webb, J. R. (2005). Gender differences in the relationship between empathy and forgiveness. The Journal of social psychology, 145(6), 673685.

Van der Wal, R. C., Karremans, J. C., \& Cillessen, A. H. (2016). Interpersonal forgiveness and psychological wellbeing in late childhood. MerrillPalmer Quarterly (1982), 62(1), 121.

Vijayakumar, L., Thara R., John, S., \&Chelleppa, S. (2006). Psychological interventions after tsunami in Tamil Nadu, India. International Review of Psychiatry, 18(3), 225-231.

Vinayak, S., \& Judge, J. (2018). Resilience and empathy as predictors of psychological well-being among adolescents. International Journal of Health Sciences \& Research 2018; 8: 192200.

Yates, T. M., Tyrell, F. A., \& Masten, A. S. (2015). Resilience theory and the practice of positive psychology from individuals to societies. Positive psychology in practice: Promoting human flourishing in work, health, education, and everyday life, 773788.

Watson, H., Rapee, R., \& Todorov, N. (2017). Forgiveness reduces anger in a school bullying context. Journal of interpersonal violence, 32(11), 16421657.

Worthington, E. L., \& Scherer, M. (2004). Forgiveness is an emotionfocused coping strategy that can reduce health risks and promote health resilience: Theory, review, and hypotheses. Psychology \& Health, 19(3), 385405.

Worthington Jr, E. L., \& Cowden, R. G. (2017). The psychology of forgiveness and its importance in South Africa. South African Journal of Psychology, 47(3), 292304. 